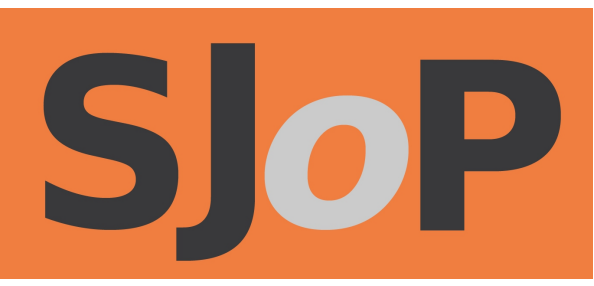

Book review: Embodied politics: dance, protest and identities, by Stacey Prickett

ANDRIA CHRISTOFIDOU

The Scottish Journal of Performance

Volume 1, Issue 2; June 2014

ISSN: 2054-1953 (Print) / ISSN: 2054-1961 (Online)

Publication details: http://www.scottishjournalofperformance.org

To cite this article: Christofidou, A., 2014. Book review: Embodied politics: dance, protest and identities, by Stacey Prickett. Scottish Journal of Performance, 1(2): pp.111-114.

To link to this article: http://dx.doi.org/10.14439/sjop.2014.0102.08

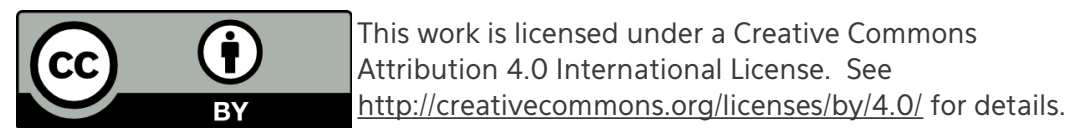




\title{
Book review: Embodied politics: dance, protest and identities, by Stacey Prickett
}

\author{
ANDRIA CHRISTOFIDOU
}

DOI: 10.14439/sjop.2014.0102.08

Publication date: 13 June 2013

Embodied politics: dance, protest and identities, by Stacey Prickett. Hampshire: Dance Books, 2013; ISBN 9781852731663 (£20.00)

There is today an increased discussion of dance as a political tool and Embodied Politics: Dance, Protest and Identities by Stacey Prickett, Principal Lecturer at Roehampton University, is a valuable contribution. Through the use of two time frames-the 1920s and 1930s, and the late twentieth and early twenty-first centuries-Prickett divides the book into four chapters to present how the body can be the medium through which dance can act as a tool for political and social protest. By focusing on four different examples in three different geographical areas-New York, San Francisco and Britain-she presents how dance pageants have acted as a means of social and economic struggle and resistance.

The book opens with a discussion of the social and political context of early twentieth century America and how this influenced the recreational dances of the time. Prickett specifically focuses on a number of informal artistic pageant events inspired and guided by Edith Segal, 'one of the outspoken reds' (p.1) who aimed to 'connect art and work and workers' (p.51), providing a detailed historical account of the Red Dancers' revolutionary dance action for social equality, workers' rights and racial empowerment. The 
thorough account of Segal's history and the new historical and interview data she provides add vastly to the existing literature. Prickett manages to situate Segal's practices into the wider socio-economic climate of uncertainty in the late 1920s and to provide an analysis of how dance assisted in, and in some cases became a means of, the workers' resistance.

The second chapter moves from the USA to Britain to discuss the socio-political conditions prior to and during the late 1920s that fed into the emergence of workers' dance groups. Prickett describes how Britain's class structure was shaped and analyses how class identities were brought into consciousness through the cultural superstructure. The author specifically refers to socialist movements and organisations that influenced the emergence of groups which established ties with workers and created 'new plays with strong class themes for amateur worker productions' (p.59). There is brief discussion of the increased institutionalisation of dance since the 1920s in Britain and the choice of some dancers to act outside these institutional structures. Prickett closes this chapter by referring to Margaret Barr's activism and the role that the Co-operative movement played in the spread of left-wing dance in Britain, which resulted in the sponsorship of folk dance groups and the integration of dance as part of the visual spectacle of late 1930s left-wing pageants.

In the third chapter, Prickett focuses on the San Francisco Bay Area which, as she argues, back in the 1930s was 'the bastion of postmodern dance theatre and performance rich in political and social themes' (p.92). Prickett considers her own performance viewing experiences, personal communication with artists, reviews, archival material and recordings of production, to focus on certain practitioners, their aesthetic style and their exploration of these social and political themes in the late twentieth and early twenty-first 
centuries. Drawing on the work of Anna Halprin, Margaret Jenkins, Joe Goode, Keith Hennessy and others, the author emphasises the importance of dance activity in that area and how it managed to influence the wider field of postmodern dance.

The final chapter of this book takes a slightly different direction and provides a discussion of South Asian dance within education and public arts frameworks in early twenty-first century Britain. With reference to the London 2012 Olympic Games and other cultural events, Prickett discusses the inclusion of multiple dance genre performances that aimed to represent Britain's multiculturalism and respect for diversity that took decades to be achieved. She provides a brief history of South Asian performance in Britain and the influence that several arts organisations and projects have had into the establishment of cross-cultural dance genres in this context. The author focuses on dance funding and institutionalisation, as well as the role of education, to discuss how these affect diversity and integration of non-Western dance genres in popular discourse.

The structure of the book-four short chapters that read as case studies-enables the reader to follow Prickett's analysis. The short sub-chapters within each chapter then allow the reader to keep focus and understand better the detailed data provided. The intended focus of the book adds vastly to the existing literature, especially since the author discusses under-analysed artists and specific pageant events rather than providing a general discussion of dance as protest. Prickett also includes some interesting visual material of images of dancers in protest. The poses of the dancers' bodies, and the way they hold objects such as swards and flags, permit the reader to conceive and analyse them as means of political and power resistance. 
Despite their positive elements and highly engaging style, some chapters do not read as part of an overall argument but rather as independent, yet informative essays. Nonetheless, this is a book that draws on many sources, makes reference to some of the most important studies in the field and uses examples which should be useful for anyone interested in the politics and history of modern (and South Asian) dance. It should be read by students, academics and dance historians who are interested in the sociology or politics of dance. This is a book that analyses dance as a practice achieved through bodies that are affected by wider socio-economic conditions, but also as a practice which is able to raise consciousness about a range of social and political issues such as class, race, gender and economic inequality. Prickett, in her conclusion, acknowledges that this is just a beginning, and she reports a range of issues that call for further exploration.

\section{About the review author}

ANDRIA CHRISTOFIDOU is a PhD candidate in Sociology at the University of Glasgow. Her $\mathrm{PhD}$ is looking at performances of masculinities and gender in ballet and contemporary dance companies and educational institutions in Scotland. Her research interests revolve around sociology of dance, cultural sociology, gender studies, queer theory and masculinities / femininities. 